\title{
Kajian Pendekatan Analogi dalam Pembelajaran Biologi yang Bermakna
}

\author{
Yuningsih $^{(1)}$, Mohamad Joko Susilo ${ }^{(2)}$ \\ ${ }^{1}$ Postgraduate Pendidikan Biologi, Program Pascasarjana Universitas Negeri \\ Yogyakarta, \\ ${ }^{2}$ Pendidikan Biologi, FKIP, Universitas Ahmad Dahlan, Yogyakarta \\ Email: 1yuningsih482@gmail.com, ${ }^{2}$ jokoms.uad@gmail.com
}

\section{Tersedia Online di \\ http://www.jurnal.unublitar.ac.id/ index.php/briliant}

\section{Sejarah Artikel}

Diterima pada 29 Mei 2018

Disetuji pada 22 Juni 2018

Dipublikasikan pada 13 Agustus

2018 Hal. 268-279

\section{Kata Kunci:}

pendekatan, analogi, pembelajaran, bermakna,

meaningful

\section{DOI:}

http://dx.doi.org/10.28926/briliant .v3i3.188

\begin{abstract}
Abstrak: Pembelajaran bermakna perlu diimplementasikan oleh setiap pendidik pada setiap materi pembelajaran, terlebih materi pembelajaran yang abstrak. Salah satu inovasinya menggunakan pendekatan analogi. Kajian ini bertujuan untuk menguraikan kekuatan analogi sebagai pendekatan untuk menciptakan pembelajaran yang bermakna. Berdasarkan hasil kajian dapat disimpulkan bahwa pendekatan analogi merupakan proses penalaran yang membandingkan dua buah obyek yang memiliki kesamaan untuk menghasilkan pengetahuan baru berdasarkan pengetahuan yang telah dimiliki peserta didik. Kekuatan analogi tidak terbatas untuk materi berupa konsep saja, melainkan jenis materi proses maupun struktur. Lebih dari itu, penggunaan analogi dalam pembelajaran menyebabkan peserta didik sulit melupakan konsep yang sudah terpatri di otak mereka.
\end{abstract}

Memasuki abad 21 pembelajaran dipersiapkan dalam rangka mewujudkan generasi masa depan yang memiliki kecakapan dalam berpikir kreatif dan menyelesaikan masalah, kreativitas dan inovasi, kolaborasi, serta komunikasi (National Education Association, 2012, p. 7). Untuk mencapai kecakapan tersebut tidak cukup dengan pembelajaran secara memorizing saja, melainkan perlu adanya inovasi pembelajaran yang relevan dan bermakna.

Pembelajaran biologi di sekolah idealnya perlu ditekankan pada pembelajaran yang berbasis kontekstual, bukan sekedar tekstual. Karena pada hakikatnya belajar biologi itu menekankan adanya interaksi antara peserta didik dengan obyek yang dipelajari. Interaksi tersebut memberikan peluang kepada peserta didik untuk berlatih belajar dan mengerti bagaimana belajar, mengembangkan potensi rasional pikir, ketrampilan, dan kepribadian serta mengenal permasalahan biologi dan pengkajiannya (Suratsih, 2010). Namun demikian, hingga saat ini pembelajaran masih cenderung terpusat pada pendidik/teacher centered-learning (Hadi, 2017).

Pembelajaran yang bermakna (meaningfull learning) sebagaimana yang digagas oleh seorang ahli psikologi pendidikan, David P. Ausubel (1963), merupakan pembelajaran yang menekankan pada pengaitan konsep baru terhadap pengetahuan relevan yang sudah dimiliki peserta didik (Novak, Gowin, \& Kahl, 1984, p. 7). Karena pada dasarnya pengetahuan itu terbentuk dari pengalaman individu yang bersangkutan. Jadi, belajar yang bermakna bukan sekedar 
menghafal, melainkan peserta didik terlibat secara langsung dalam menemukan konsep serta menghubungkannya menjadi suatu pengetahuan yang utuh. Belajar yang demikian melibatkan sistem indra yang lebih banyak daripada sekedar mendengarkan penjelasan pendidik. Alhasil, apabila suatu konsep sudah terpatri di otak peserta didik, sering kali konsep tersebut sulit untuk dilupakan.

Pembelajaran bermakna perlu diimplementasikan oleh setiap pendidik pada setiap materi pembelajaran. Terlebih materi pembelajaran yang sifatnya abstrak, sulit dibayangkan, dan tidak tampak dengan mata telanjang. Meskipun demikian, peserta didik terlebih dahulu perlu diberikan motivasi intrinsik supaya lebih semangat dan membangkitkan rasa keingintahuannya. Hasil yang akan diperoleh peserta didik akan merasakan bahwa materi yang dipelajari begitu bermakna bagi mereka.

Meskipun demikian, untuk dapat mengaitkan pengetahuan lama dengan pengetahuan baru, terkadang siswa mengalami kesulitan. Dalam keadaan seperti ini perlu adanya jembatan penghubung, salah satunya berupa pendekatan analogi. Pendekatan analogi merupakan pendekatan pembelajaran dengan cara membandingkan dua obyek atau fenomena yang dianggap memiliki kesamaan tertentu, baik misalnya bentuk, struktur maupun fungsinya. Pembelajaran dengan analogi melalui metode yang telah digagas oleh para ahli, misalnya metode FAR dipercaya mampu memotivasi peserta didik dan meningkatkan pemahaman mereka terhadap konsep sains yang diajarkan (Harrison \& Coll, 2013, pp. 38 \& 41). Di samping itu, pendekatan analogi dalam pembelajaran juga dapat meningkatkan daya penalaran peserta didik (Subali, Paidi, \& Mariyam, 2015, p. 22). Pendekatan analogi sebagaimana penelitian yang telah dilakukan oleh Yuningsih (2017b) dapat meningkatkan kreativitas peserta didik berdasarkan pola berpikir divergen. Sedangkan, penggunaan pendekatan analogi dari hasil penelitian oleh Aziri \& Ahmad (2014) dapat meningkatkan hasil belajar peserta didik, peserta didik memiliki pemahaman yang lebih mendalam, dan pembelajaran lebih berkesan.

Oleh sebab itu, pentingnya pendekatan analogi ini untuk menciptakan pembelajaran yang bermakna, sehingga peserta didik tidak sekedar menghafal, melainkan lebih mampu menggunakan daya imajinasi, kreativitas serta inovasinya dalam mempelajari setiap konsep/materi pelajaran. Dengan demikian, kajian ini disusun dalam rangka untuk menguraikan kekuatan analogi sebagai pendekatan untuk menciptakan pembelajaran yang bermakna.

\section{PEMBAHASAN \\ Pendekatan Analogi}

Di dalam KBBI dijelaskan bahwa (1) analogi merupakan persamaan atau persesuaian antara dua benda atau hal yang berlainan, kias; (2) analogi merupakan kesepadanan antara bentuk bahasa yang menjadi dasar terjadinya bentuk lain; (3) analogi merupakan sesuatu yang sama dalam bentuk, susunan, atau fungsi, tetapi berlainan asal-usulnya sehingga tidak ada hubungan kekerabatan; (4) analogi adalah kesamaan sebagian ciri antara dua benda atau hal yang dapat dipakai untuk dasar perbandingan. Sementara, menganalogikan adalah membuat sesuatu yang baru berdasarkan contoh yang sudah ada, mereka-reka bentuk kata baru dengan mencontohkan bentuk yang telah ada (Kamus Besar Bahasa Indonesia, 2002). 
Analogi sering kali digunakan untuk mendeskripsikan fenomena yang bermacam-macam tetapi saling berhubungan dan konteksnya sama (Samara, 2016). Umumnya, analogi merupakan mekanisme untuk menunjukkan hubungan struktur diantara dua sistem, domain, atau konsep yang bervariasi jumlah feature/kesamaanya (Asay, 2013). Analogi ini termasuk penalaran induktif yaitu proses penalaran suatu fenomena terhadap fenomena lain yang sejenis, sehingga apabila kedua benda beranalogi maka fenomena yang terjadi pada benda pertama akan terjadi pada benda yang lain (Hajar \& Budi, 2014).

Di dalam pembelajaran, analogi sering dikaitkan dengan penalaran (reasoning) yang merupakan bagian kemampuan berpikir tingkat tinggi peserta didik (HOTs). Penalaran ini dapat terjadi melalui serangkaian proses mulai dari peserta didik mengungkap kembali pengetahuan yang dimiliki atau mereka dihadapkan dengan sejumlah fakta-fakta, kemudian mereka bertugas mencari kesamaannya dengan cara memetakan kesamaan tersebut. Peserta didik melakukan evaluasi atas ketepatan pemetaan kesamaan. Selanjutnya, peserta didik bertugas menarik kesimpulan dan mengorganisaikan informasi baru. Kunci keberhasilan penganalogian ini terletak pada kekuatan dari sejumlah pengetahuan, kajian teori, pengalaman, maupun wawasan lain yang telah dimiliki peserta didik.

Di dalam pembelajaran sains, analogi ini dianggap sebagai suatu pendekatan yang menarik serta cara yang cepat untuk menjelaskan obyek sains yang tidak tampak, seperti gen, atom, enzim, dan lain-lain (Harrison \& Coll, 2013, p. 28). Jadi, dapat ditarik kesimpulan bahwa pendekatan analogi merupakan proses penalaran yang membandingkan dua buah obyek/fenomena yang memiliki kesamaan untuk menghasilkan pengetahuan baru berdasarkan pengetahuan yang telah dimiliki peserta didik. Pendekatan analogi ini berperan sebagai jembatan penghubung untuk memahamkan materi yang sulit terjangkau oleh peserta didik melalui fenomena/obyek di sekitar yang familiar bagi mereka.

\section{Representasi Analogi dalam Pembelajaran}

Analogi dapat digambarkan dengan mengidentifikasi persamaan diantara dua konsep (Glynn, 2008). Materi/konsep yang belum familiar diproyeksikan ke dalam konsep yang sudah familiar oleh siswa. Misalnya, analogi sel dengan sebuah kota. Analogi dalam hal ini bertindak sebagai penjelas konsep-konsep materi sel yang sulit dibayangkan oleh siswa, sementara siswa tidak asing lagi dengan kota. Ibarat sebuah kota, terdapat bangunan-bangunan dengan fungsi masing-masing. Demikian halnya sel, memiliki organel-organel yang fungsinya berbeda-beda. PLN diibaratkan sebagai mitokondria sebagai tempat penghasil energy, warung makan diibaratkan sebagai kloroplas sebagai tempat fotosintesis/penghasil makanan bagi tumbuhan, dan seterusnya. Konsep-konsep yang familiar tersebut oleh Glynn disebut sebagai analog, sedangkan konsep yang belum familiar disebut sebagai target. Analog dan target memiliki kesamaan secara kedudukan maupun konseptual, tergatung tujuan dari penggunaan analogi. Kedua konsep tersebut dapat direpresentasikan sebagaimana Gambar 1 berikut. 


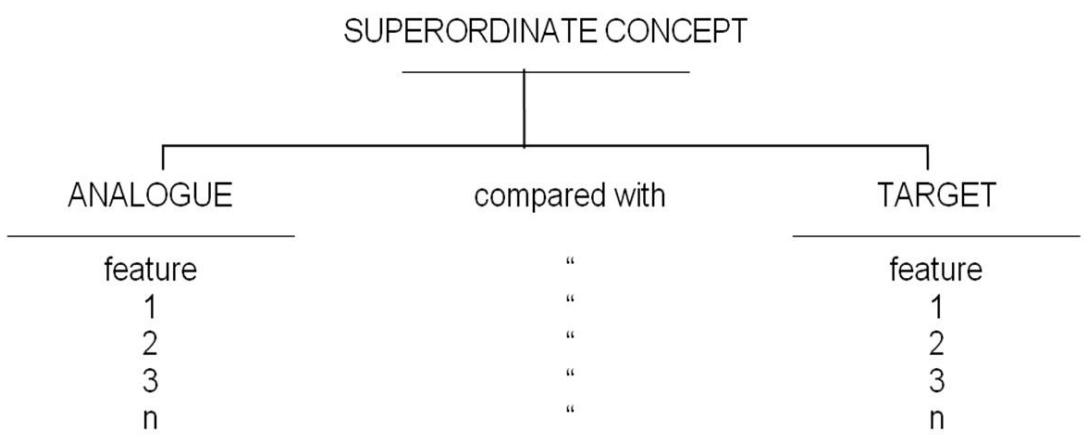

Gambar 1. Representasi Analogi (Sumber: Glynn, 2008, p. 114)

\section{Macam-Macam Analogi dan Penggunaannya}

Thiele \& Treagust (1992), menggolongkan analogi menjadi 3: analogi verbal, analogi pictorial, dan analogi personal

Analogi verbal dan pictorial oleh sering kali digunakan saat presentasi, baik dalam bentuk teks maupun oral. Analogi ini biasanya disertakan gambar yang mempermudah perbandingan dan kesimpulan dari target analogi. Analogi pictorial dan verbal ini sering kali penggunaannya dilakukan secara spontan bersamaan dan saling melengkapi, sehingga diistilahkan sebagai pictorial-verbal analogies (Thiele \& Treagust, 1992). Contoh analogi pictorial dalam pembelajaran fotosintesis dapat disajikan pada Gambar 2 berikut.

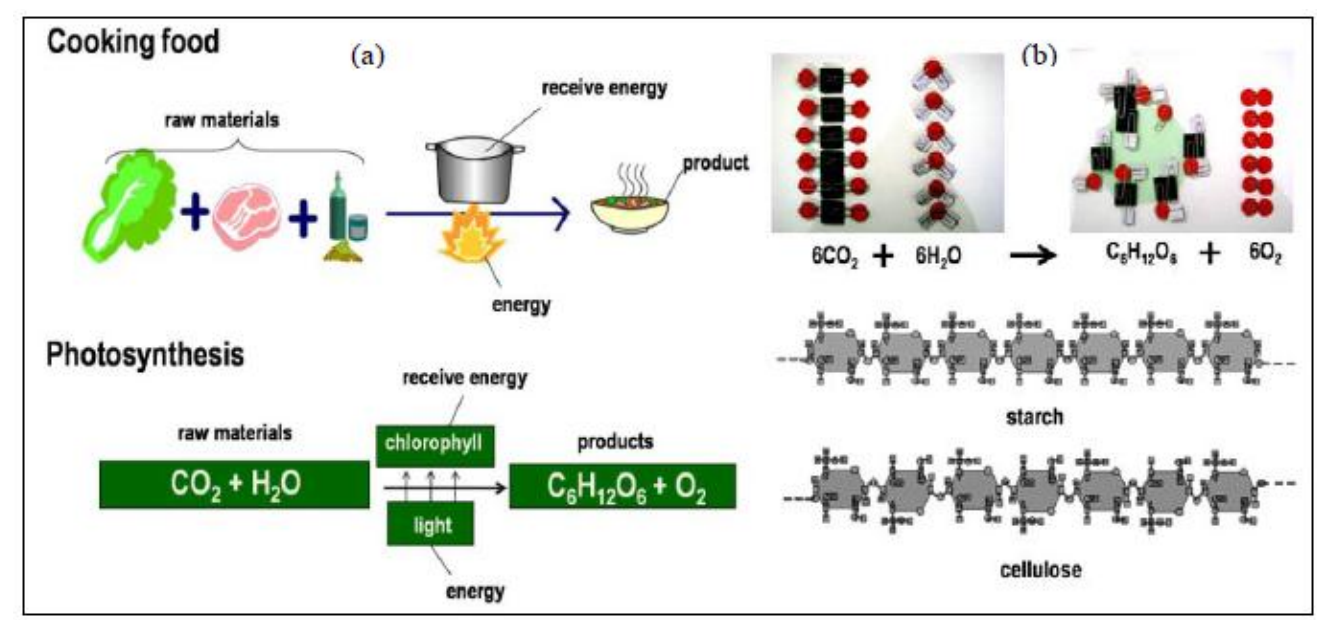

Gambar 2. Analogi Pictorial dan Model Paper-Clip Fotosintesis (Sumber: Wichaidit, Dechsri, \& Chaivisuthangkura, 2011)

Analogi personal dipercaya dapat membantu siswa memberikan intuisi terhadap suatu obyek benda mati dengan suatu konsep. Caranya dengan menghubungkan konsep abstrak terhadap fenomena yang tampak seperti orang, uang, maupun makanan (Thiele \& Treagust, 1992). Contohnya, pembuluh nadi itu seperti selang air; struktur atom seperti roti kismis (analogi ini didasarkan pada tori atom oleh JJ. Thomson pada tahun 1897); maupun analogi reaksi terang pada proses fotosintesis dengan kontraktor bangunan (Gambar 3). 


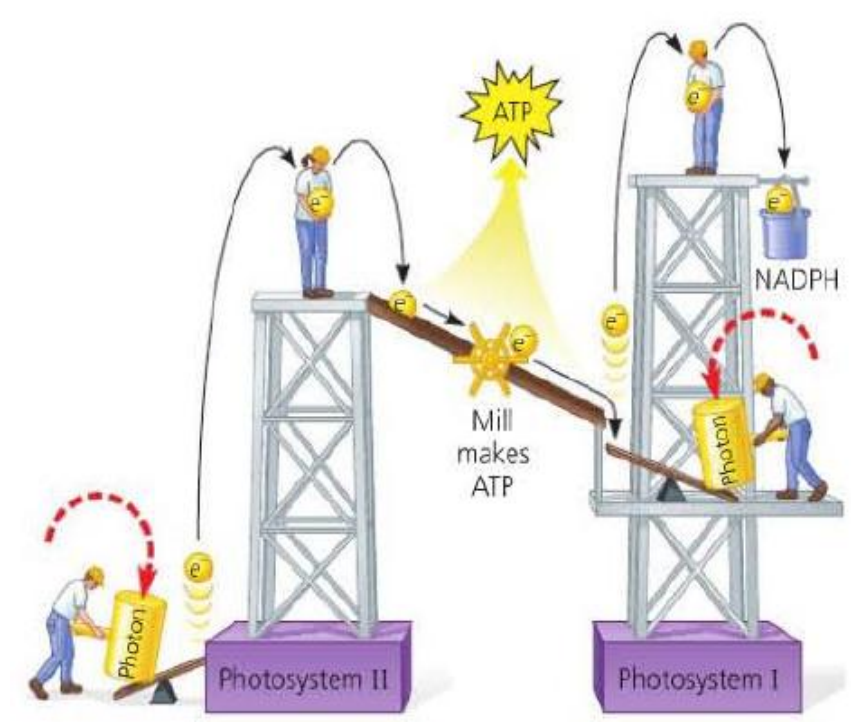

\section{Gambar 3. Analogi Reaksi Terang dengan Kontraktor Bangunan} (sumber: Campbell et al., 2008, p. 195)

\section{Penggolongan Analogi Berdasarkan Keluasan Konten}

Analogi dalam penggolongan ini dibedakan menjadi 3: analogi sederhana, analogi diperkaya, dan analogi diperluas. Perbedaan analogi sederhana dan analogi diperkaya terletak pada konten penjelas dari suatu konsep. Analogi sederhana berupa deskriptif, istilah lainnya adalah analogi single(Dikmenli, 2015; Duit, 1991). Contoh analogi sederhana bahwa sel itu seperti kotak (analogi ini didasarkan pada pertama kali pengamatan sel gabus oleh Robert Hooke pada tahun 1665). Analogi diperkaya dilengkapi dengan penjelasan cara kerja misalnya, cara kerjanya enzim itu seperti kunci dan gembok (lock \& key) yang dipopulerkan oleh Emil Fischer. Keduanya memiliki sisi aktif tertentu untuk dapat bekerja dengan baik dan kerja enzim spesifik. Apabila terdapat inhibitor yang telah menempati sisi aktif, maka cara kerja enzim terhambat. Analogi diperluas mengandung pemetaan yang sederhana dan diperluas, misalnya mata itu seperti sebuah kamera. Bagian-bagian mata seperti lensa memiliki kesamaan dengan lensa pada kamera, bagian pipil memiliki kesamaan dengan bidik kamera, bagian iris mata sama dengan diafragma, bagian retina sama fungsinya dengan film, dan bagian ruang yang membalikkan bayangan pada mata juga memiliki kesamaan pada bagian kamera. Adapun perbedaannya terletak pada cara kerja fokus mata manusia melalui kornea dengan otot mata di sekitar lensa, sedangkan fokus pada kamera dapat dilakukan dengan cara mengubah jarak antara lensa dengan film (Glynn, 1995; Harrison \& Coll, 2013, p. 23; Salih, 2010).

\section{Penggolongan Analogi Berdasarkan Kedudukan}

Analogi dapat digunakan secara struktural yang membandingkan dua benda yang memiliki persamaan struktur, contohnya analogi sel hewan dengan pabrik, analogi mata dengan kamera, analogi atom dengan roti kismis. Adapun analogi fungsional digunakan untuk membandingkan dua buah fenomena atau benda yang memiliki persamaan fungsi, misalnya analogi ekosistem sawah dengan ekosistem kolam. Di dalam ekosistem sawah terdapat padi yang berperan sebagai produsen, sementara di dalam ekosistem kolam terdapat lumut, tanaman 
air yang peran sebagai produsen dengan fungsi yang sama untuk berfotosintesis. Di dalam ekosistem sawah terdapat organisme berkedudukan sebagai konsumen tingkat I misalnya keong emas, sedangkan konsumen tingkat I di ekosistem kolam adanya serangga air, demikian seterusnya (Yuningsih, 2017b).

Dalam biologi, ada juga istilah analogi dan homologi. Analogi dalam hal ini merupakan organ-organ makhluk hidup yang memiliki struktur dasar sama, sedangkan fungsinya berbeda misalnya analogi tangan manusia dengan sayap burung. Struktur dasar tangan manusia dengan sayap burung memiliki kesamaan, tetapi fungsi tangan manusia untuk membantu beraktivitas, mengangkat, mengambil benda, mengetik, dan lain-lain sedangkan sayap burung fungsinya untuk terbang. Sebaliknya, homologi dalam biologi merupakan organ yang memiliki kesamaan fungsi, sedangkan struktur dasarnya berbeda. Contohnya homologi sayap burung dengan sayap pinguin. Keduanya berupa sayap, namun pada penguin bukan untuk terbang melainkan untuk membantu pergerakan mengambil benda, membantu berenang dan lain-lain (Campbell et al., 2008, p. 541).

\section{Penggolongan Analogi Berdasarkan Level Abstraksi}

Analogi berdasarkan level abstraksi menurut Dikmenli (2015) dapat digolongkan menjadi 3, konkret-konkret, abstrak-abstrak, konkret-abstrak. Analogi antarbenda/fenomena yang konkret menghadirkan konsep analog dan target yang keduanya nyata/dapat dilihat secara visual, sebagai contoh analogi dari ekosistem hutan dengan ekosistem sungai (Yuningsih, 2017b). Analogi antarbenda/fenomena yang abstrak menghadirkan konsep analog dan target yang keduanya bersifat abstrak/tidak tampak dengan mata telanjang. Analogi konkret dengan abstrak merupakan analogi yang pada umumnya digunakan, misalnya analogi sel dengan pabrik (Glynn \& Takahashi, 1998), analogi enzim dengan kereta kencana (Aziri \& Ahmad, 2014), dan lain-lain. Jenis analogi konkretabstrak ini disebut juga analogi deklaratif. Analogi deklaratif atau penjelas merupakan metode untuk menegaskan sesuatu materi/konsep yang abstrak (belum familiar) dengan menggunakan hal yang sudah familiar dengan peserta didik (Glynn, 1994).

\section{Metode Pembelajaran dalam Penerapan Pendekatan Analogi Metode FAR (The Focus, Action, Reflect)}

FAR merupakan kepanjangan dari Fokus, Aksi, dan Refleksi. Hal-hal yang perlu diketahui peserta didik sebelum pembelajaran dengan analogi antara lain: mengenai tujuan digunakannya analogi, obyek yang dijadikan sebagai analog harus familiar, serta perlu dipastikan bagian analog yang dapat digunakan dengan yang tidak dapat. Pada tahap fokus, pendidik perlu mengidentifikasi a) konsep materi, apakah tergolong materi yang sulit, asing, ataukah abstrak; b) gagasan apa yang sebelumnya telah diketahui peserta didik terkait dengan konsep yang akan dipelajari; dan c) apakah analog yang digunakan sudah dikenal baik oleh peserta didik atau asing bagi mereka. Pada tahap aksi, peserta didik bertugas mendiskusikan bagian-bagian analog yang memiliki kemiripan dengan konsep yang dipelajari dengan yang tidak memiliki kemiripan. Berikutnya, peserta didik dapat memetakan kesamaan diantara kedua konsep sebagaimana representasi analogi Gambar 1. Tahap refleksi merupakan evaluasi bagi seorang guru terhadap 
keefektifan dalam penggunaan analogi. Apakah analogi cukup membingungkan peserta didik atau justru mempermudah pembelajaran sehingga tujuan tercapai (Harrison \& Coll, 2013, p. 3; Treagust, Horrison, \& Vencille, 1998).

\section{Metode TWA (Teaching With Analogy)}

Metode TWA ini dikembangkan oleh Glynn, dengan langkah-langkah: 1) memperkenalkan konsep target; 2) mengingatkan kembali kepada peserta didik tentang pengetahuan mereka terhadap konsep analog; 3) mengidentifikasi kersamaan kedua konsep (analog dan target); 4) menghubungkan/memetakan persamaan dari kedua konsep, 5) menunjukkan bagian analogi yang tidak relevan, dan 6) menarik kesimpulan tentang konsep yang dipelajari (Glynn, 2008, p. 118).

\section{Metode GMAT}

GMAT kepanjangan dari The General Model of Analogy Teaching merupakan metode pembelajaran dengan menggunakan analogi yang digagas oleh Zeitoun (1984). Langkah-langkahnya meliputi: 1) mengukur karakteristik peserta didik dihubungkan dengan pembelajaran analogi pada umumnya; 2) menilai konsep prioritas terkait topik yang akan diajarkan; 3) menganalisis materi pembelajaran sesuai topik yang akan dipelajari; 4) memutuskan analogi yang tepat untuk digunakan; 5) menentukan karakteristik analogi yang akan digunakan; 6) memilih strategi pembelajaran dan menyiapkan analogi yang lebih mudah dipahami; 7) menyajikan analogi untuk peserta didik; 8) mengevaluasi ketercapaian penggunaan analogi dalam pembelajaran; dan 9) merevisi tahapan metode apabila terdapat kesenjangan selama pembelajaran berlangsung.

\section{Jenis Materi yang Cocok Diajarkan dengan Pendekatan Analogi}

Analogi dapat meningkatkan pembelajaran pada materi berupa konsep. Misalnya konsep ekosistem, kedudukan komponen-komponennya, serta perannya sebagai bagian penyusun ekosistem (Yuningsih, 2017b) maupun konsep alel mutan dominan (Seipelt-thiemann, 2012). Analogi juga dapat menjelaskan materi berupa proses, misalnya proses fotosintesis (Wichaidit et al., 2011); proses kerja enzim (Aziri \& Ahmad, 2014). Selain itu, analogi juga dapat digunakan untuk meteri berupa struktur, misalnya struktur sel hewan yang dianalogikan dengan sebuah pabrik (Glynn \& Takahashi, 1998) maupun untuk mempelajari sistem yang lebih kompleks misalnya melalui eksperimen dari model sistem tata surya untuk mempelajari konsep peredaran atom (Vendetti, Matlen, Richland, \& Bunge, 2015). Jenis materi proses lebih efektif menggunakan analogi daripada materi berupa struktur (Harrison \& Coll, 2013, p. 23). 


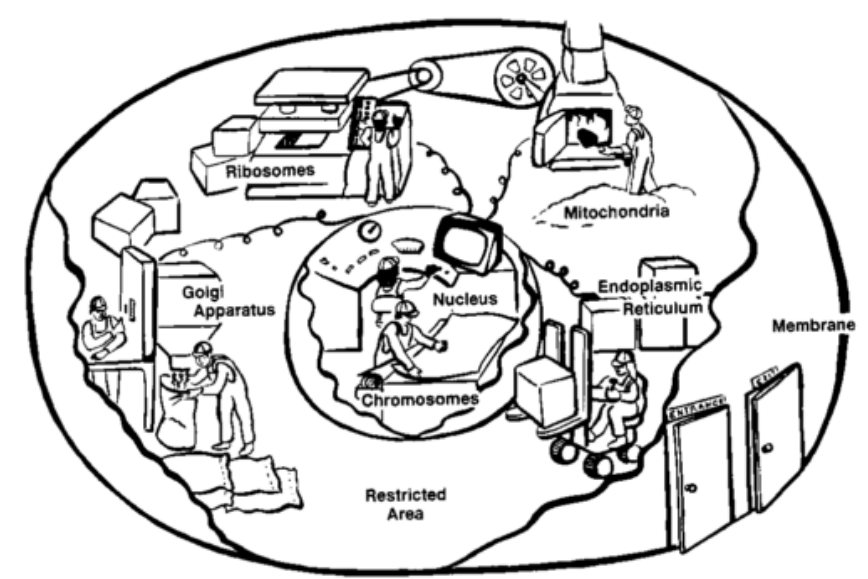

\section{Gambar 4. Analogi Sel Hewan dengan Pabrik} (Sumber: Glynn \& Takahashi, 1998)

\section{Pembelajaran Biologi dengan Pendekatan Analogi Model 1}

Pada model 1 pembelajaran dengan pendekatan analogi sebagaimana yang telah dikembangkan oleh Yuningsih (2017), mengikuti metode TWA oleh Glynn dengan tipe analogi konkret-konkret untuk materi berupa konsep. Peserta didik disajikan tabel sebagaimana Gambar 5 berikut. Oleh karena peserta didik sudah memiliki dasar dari materi ekosistem ini, tentu bagi mereka bukanlah sesuatu yang sulit. Analogi dalam hal ini dilakukan dalam rangka untuk membandingkan jenis interaksi komponen-komponen ekosistem, baik ekosistem hutan, ekosistem padang rumput, maupun ekosistem gurun. Setelah peserta didik menjawab seluruh pertanyaan, berikutnya disajikan soal-soal yang mengarah pada kesimpulan.

\begin{tabular}{|l|l|l|l|}
\hline \multirow{1}{*}{$\begin{array}{c}\text { Jenis } \\
\text { interaksi }\end{array}$} & \multicolumn{3}{|c|}{ Contoh Interaksi Ekosistem } \\
\cline { 2 - 4 } & $\begin{array}{c}\text { Ekosistem } \\
\text { Hutan }\end{array}$ & $\begin{array}{c}\text { Ekosistem } \\
\text { Padang } \\
\text { Rumput }\end{array}$ & $\begin{array}{c}\text { Ekosistem } \\
\text { Gurun }\end{array}$ \\
\hline Predasi & & & \\
\hline Kompetisi & & & \\
\hline $\begin{array}{l}\text { Simbiosis } \\
\text { Mutualism } \\
\text { e }\end{array}$ & & & \\
\hline $\begin{array}{l}\text { Simbiosis } \\
\text { Komensali } \\
\text { sme }\end{array}$ & & & \\
\hline $\begin{array}{l}\text { Simbiosis } \\
\text { Parasitism } \\
\text { e }\end{array}$ & & & \\
\hline Netral & & & \\
\hline Lain-lain & & & \\
\hline
\end{tabular}

Berdasarkan interaksi makhluk hidup yang kalian susun tersebut, apa yang dapat kalian simpulkan?

Jawab:

Gambar 5. Analogi Pada Sub-Materi Interaksi Antarkomponen Ekosistem (Sumber: Yuningsih, 2017a) 


\section{Pembelajaran Biologi dengan Pendekatan Analogi Model 2}

Pada model 2 pembelajaran dengan pendekatan analogi menggunakan metode FAR dengan tipe analogi konkret-abstrak untuk materi berupa struktur.

\section{Tabel 1. Metode FAR untuk Mengajar Materi Sel}

\begin{tabular}{|c|c|c|}
\hline \multirow[t]{3}{*}{ Fokus } & Konsep & $\begin{array}{l}\text { Sel berwujud abstrak, mikroskopis, sulit dipahami } \\
\text { peserta didik SMA. }\end{array}$ \\
\hline & Murid & $\begin{array}{l}\text { Peserta didik sudah memiliki dasar konsep tentang sel } \\
\text { karena sudah dipelajari pada jenjang sebelumnya. }\end{array}$ \\
\hline & Analog & $\begin{array}{l}\text { Peserta didik sudah familiar dengan analogi kota, seperti } \\
\text { PLN, bangunan-bangunan, rumah sakit, dan lain-lain. }\end{array}$ \\
\hline \multirow[t]{2}{*}{$A k s i$} & Mirip & $\begin{array}{l}\text { Pendidik menggambarkan ciri-ciri sebuah kota yang } \\
\text { mirip dengan sel, misalnya PLN sebagai pusat penghasil } \\
\text { energi beranalogi dengan mitokondria; badan golgi } \\
\text { beranalogi dengan pabrik yang keduanya memproduksi } \\
\text { bahan-bahan yang digunakan di luar sel atau kota, dan } \\
\text { lain-lain. }\end{array}$ \\
\hline & Tidak mirip & $\begin{array}{l}\text { Kebanyakan kota tidak memiliki dinding yang } \\
\text { mengelilinginya, sedangkan sel memiliki; sel dipenuhi } \\
\text { dengan cairan sitoplasma, sedangkan kota tidak; dan } \\
\text { setiap sel berdekatan dengan sel lain, sedangkan kota } \\
\text { tidak demikian. }\end{array}$ \\
\hline \multirow[t]{2}{*}{ Refleksi } & Kesimpulan & $\begin{array}{l}\text { Pendidik dapat melakukan wawancara dan memeriksa } \\
\text { pekerjaan peserta didik untuk memastikan bahwa analogi } \\
\text { yang digunakan sesuai dengan konsep target. }\end{array}$ \\
\hline & Perbaikan & $\begin{array}{l}\text { Pendidik dapat mengevaluasi atas penggunaan analogi } \\
\text { dalam pembelajaran sel sebagai bentuk perbaikan } \\
\text { maupun masukan pada kesempatan berikutnya. }\end{array}$ \\
\hline
\end{tabular}

Sumber: (Harrison \& Coll, 2013, pp. 33-34).

Lebih lengkapnya, penugasan dapat disajikan pada lembar kerja peserta didik seperti berikut.

\section{Lembar Kerja Kelompok}

Organel-organel sel memiliki kemiripan dengan bagian-bagian kota. Diskusikan bersama teman sekelompok, bagian-bagian manakah yang memiliki kesamaan tersebut. Silakan merujuk butu teks pelajaran. Tulis semua fungsi organel bagian kota menurut kelompok kalian yang memiliki kemiripan! Di bawah ini ada sebuah contoh yang dapat Anda ikuti.

\begin{tabular}{|c|l|l|}
\hline Sel & \multicolumn{1}{|c|}{ Fungsi } & \multicolumn{1}{c|}{ Kota } \\
\hline \multicolumn{3}{|c|}{ Bagaimana Kemiripan Sel dengan Kota } \\
\hline Inti Sel & $\begin{array}{l}\text { Inti sel mengontrol dan } \\
\text { mengkoordinasikan semua } \\
\text { struktur dan fungsi sel, sehingga } \\
\text { seluruh bagiannya bekerja sama. }\end{array}$ & $\begin{array}{l}\text { Pemerintah Kota mengatur jalan, } \\
\text { bangunan, dan pasar dengan } \\
\text { membuat kebijakan dan } \\
\text { mengontrol penerapannya. }\end{array}$ \\
\hline & & \\
\hline & & \\
\hline
\end{tabular}

276 BRILIANT: Jurnal Riset dan Konseptual

Volume 3 Nomor 3, Agustus 2018 


\begin{tabular}{|l|l|l|}
\hline \multicolumn{1}{|c|}{ Sel } & \multicolumn{1}{|c|}{ Fungsi } & \multicolumn{1}{c|}{ Kota } \\
\hline \multicolumn{3}{|c|}{ Bagaimana Ketidakmiripan Sel dengan Kota } \\
\hline $\begin{array}{l}\text { Dinding } \\
\text { Sel }\end{array}$ & $\begin{array}{l}\text { Sel memiliki dinding yang } \\
\text { melindungi isi sel }\end{array}$ & $\begin{array}{l}\text { Kebanyakan kota tidak memiliki } \\
\text { dinding yang mengelilinginya }\end{array}$ \\
\hline & & \\
\hline & & \\
\hline
\end{tabular}

Sumber : (Harrison \& Coll, 2013, p. 35).

\section{Manfaat Penggunaan Pendekatan Analogi}

Penggunaan analogi dalam pembelajaran berguna untuk: 1) merangsang kreativitas dan berpikir kritis; 2) mendorong daya nalar peserta didik; 3) menghasilkan wawasan baru bagi peserta didik berdasarkan pengalaman hidup mereka; 4) mengajarkan sesuatu yang secara kontekstual sesuai dengan kebutuhan lingkungan belajar; 5) sebagai alat penilai diagnostik (Mayo \& College, 2006; Yuningsih, 2017b); 6) menyederhanakan ide-ide yang kompleks dan mempermudah peserta didik dalam mengkonseptualisasikan konsep abstrak ; 7) melibatkan pemikiran peserta didik atas pengetahuan yang telah dimiliki; 8) menjadikan pembelajaran lebih rasional dan penuh makna (meaningfull); 9) menumbuhkan motivasi intrinsik peserta didik melalui proses penggabungan pengetahuan baru dengan pengetahuan yang sudah dimiliki; 10) efisiensi peserta didik dalam memahami fenomena baru dan menyelesaikan persoalan melalui pengalaman yang pernah dilakukan (Glynn, 1994, pp. 18-19); 11) memotivasi peserta didik; dan 12) meningkatkan pemahaman peserta didik terhadap konsep materi yang diajarkan (Harrison \& Coll, 2013, pp. 38 \& 41).

Keindahan analogi dengan sentuhan imajinasi dapat membantu peserta didik lebih banyak belajar tentang konsep materi. Lebih dari itu, peserta didik tidak memperoleh pengetahuan tentang konsep target saja, melainkan secara tidak langsung mereka juga mengingatkan kembali atau memperdalam pengetahuan tentang konsep analog sekaligus.

\section{KESIMPULAN}

Berdasarkan hasil kajian dapat disimpulkan bahwa pendekatan analogi merupakan proses penalaran yang membandingkan dua buah obyek yang memiliki kesamaan untuk menghasilkan pengetahuan baru berdasarkan pengetahuan yang telah dimiliki peserta didik. Pendekatan analogi ini berperan sebagai jembatan penghubung untuk memahamkan materi yang sulit terjangkau oleh peserta didik melalui fenomena/obyek di sekitar yang familiar bagi mereka. Kekuatan analogi tidak terbatas untuk materi berupa konsep saja melainkan jenis materi proses maupun struktur. Lebih dari itu, adanya penggunaan analogi dalam pembelajaran menyebabkan peserta didik sulit melupakan konsep yang sudah terpatri di otak mereka.

\section{SARAN}

Berdasarkan kajian yang telah disusun dapat disarankan bahwa untuk menerapkan pendekatan analogi ini terlebih diperlukan persiapan dan penguasaan konsep yang utuh dan matang terutama dari pendidik. Pendidik juga perlu memanajemen waktu pembelajaran dengan baik supaya tidak terlena, karena 
pembelajarannya memang lucu dan menarik. Pendidik harus terampil dalam menguraikan kelemahan/bagian di luar konsep analogi. Terakhir, pendidik perlu memaksimalkan pada bagian pembahasan dari argumen (analogi yang disusun) peserta didik, karena disitulah letak kreativitas dan imajinasi mereka.

\section{DAFTAR RUJUKAN}

Asay, L. J. (2013). The importance of explicitly mapping instructional analogies in science education. University of Nevada, Las Vegas.

Aziri, S. S. M., \& Ahmad, C. N. C. (2014). Penggunaan modul pembelajaran dan pengajaran berasaskan analogi terhadap pencapaian pelajar bagi topik enzim dalam biologi tingkatan 4. Jurnal Pendidikan Sains \& Matematik Malaysia, 4(2), 91-103.

Campbell, N. A., Reece, J. B., Urry, L. A., Cain, M. L., Wasserman, S. A., \& Jackson, R. B. (2008). Biology (8th ed.). San Francisco: Pearson Benjamin Cummings.

Dikmenli, M. (2015). A study on analogies used in new ninth grade biology textbook. Asia-Pacific Forum on Science Learning and Teaching, 16(1), $1-20$.

Duit, R. (1991). On the role of analogies and metaphors in learning science. Science Education, 75(6), 649-672. https://doi.org/10.1002/sce.3730750606

Glynn, S. M. (1994). Teaching science with analogy: A strategy for teacher and textbook authors. USA.

Glynn, S. M. (1995). Conceptual bridges: Using analogies to explain scientific concepts. The Science Teacher, 62(9), 25-27.

Glynn, S. M. (2008). Making science concepts meaningful to students: Teaching with analogies. In Four Decades of Research in Science Education: From Curriculum Development to Quality Improvement (pp. 113-125).

Glynn, S. M., \& Takahashi, T. (1998). Learning from analogy-enhanced science text. Journal of Research in Science Teaching, 35(10), 1129-1149. https://doi.org/10.1002/(SICI)1098-2736(199812)35:10<1129::AIDTEA5>3.0.CO;2-2

Hadi, S. (2017). Story-telling: Upaya meningkatkan daya simak dalam keterampilan menyimak interaktif berbahasa. Brilliant: Jurnal Riset Dan Konseptual, 2(2),

163-177. https://doi.org/http://dx.doi.org/10.28926/briliant.v2i2.42

Hajar, I., \& Budi, L. G. P. A. (2014). Penerapan strategi belajar analogi dalam model pembelajaran langsung pada standar kompetensi menerapkan dasar-dasar teknik digital di SMK Negeri 5 Surabaya. Jurnal Pendidikan Teknik Elektro, 3(3), 31-37.

Harrison, A. G., \& Coll, R. K. (2013). Analogi dalam kelas sains: Panduan FAR cara menarik untuk mengajar dengan menggunakan analogi. (Tim Indeks, Ed.). Jakarta: PT Indeks.

Kamus Besar Bahasa Indonesia. (2002). Kamus Besar Bahasa Indonesia (3rd ed.). Jakarta: Balai Pustaka.

Mayo, J., \& College, G. (2006). Reflective pedagogy through analogy. Southeastern Journal of Psychology, 1-6.

National Education Association. (2012). Preparing 21st century students for a 
global society: An educator's guide to the "four cs". Retrieved June 1, 2017, from http://www.nea.org/assets/docs/A-Guide-to-Four-Cs.pdf

Novak, J. D., Gowin, B. D., \& Kahl, J. B. (1984). Learning how to learn. New York: Cmbridge University Press.

Salih, M. (2010). Developing thinking skills in Malaysian science students via an analogical task. Journal of Science and Mathematics Education in ..., 33(1), 110-128. Retrieved from http://www.recsam.edu.my/R\&D_Journals/YEAR2010/june2010vol1/ma riah(110-128).pdf

Samara, N. A. H. (2016). Effectiveness of analogy instructional strategy on undergraduate student's acquisition of organic chemistry concepts in Mutah University, Jordan. Journal of Education and Practice, 7(8), 7074.

Retrieved

from

http://search.ebscohost.com/login.aspx?direct=true \&db=eric\&AN=EJ109 $5360 \&$ site $=$ ehost-live

Seipelt-thiemann, R. L. (2012). Analogies for Teaching Mutant Allele Dominance Concepts, 3(October), 884-889. https://doi.org/10.4236/ce.2012.326133

Subali, B., Paidi, \& Mariyam, S. (2015). Pengembangan kreativitas: Keterampilan proses sains aspek kehidupan pada mata pelajaran IPA di sekolah dasar beserta cara pengukuran keasliannya. (Rohali, Ed.). Yogyakarta: UNY Press.

Suratsih. (2010). Pengembangan modul pembelajaran biologi berbasis potensi lokal dalam kerangka implementasi ktsp sma di Yogyakarta. Yogyakarta.

Thiele, R. B., \& Treagust, D. F. (1992). Analogies in senior high school chemistry textbooks: A critical analysis. In ICASE Research Conference in Chemistry and Physics Education. Dortmund, Germany.

Treagust, D. F., Horrison, A. G., \& Vencille, G. (1998). Teaching science effectively with analogies: An approach for pre-service and in-service teacher education. Journal of Science Teacher Education, 9, 85-101.

Vendetti, M. S., Matlen, B. J., Richland, L. E., \& Bunge, S. A. (2015). Analogical reasoning in the classroom: Insights from cognitive science. International Mind, Brain, and Education Society and Wiley Periodicals, Inc, 9(2), 100-106.

Wichaidit, S., Dechsri, P., \& Chaivisuthangkura, P. (2011). Using analogy and model to enhance conceptual change in Thai middle school students. USChina Education Review, 8(3), 333-338.

Yuningsih. (2017a). Analogipedia. Yogyakarta: Pintarstudio. Retrieved from https://play.google.com/store/apps/details?id=com.pintarstudio.analogipe dia

Yuningsih. (2017b). Pengembangan modul pbl berbasis android menggunakan pendekatan analogi untuk meningkatkan kreativitas berdasarkan pola berpikir divergen siswa sma. Universitas Negeri Yogyakarta. Retrieved from eprints.uny.ac.id/53412

Zeitoun, H. H. (1984). Teaching scientific analogies: A proposed model. Journal Research in Science \& Technological Education, 2(2), 107-125. https://doi.org/https://doi.org/10.1080/0263514840020203. 